Електронне "Державне управління: удосконалення та розвиток" включено до переліку наукових фахових видань України з питань державного управління (Наказ Міністерства освіти і науки України від 22.12.2016 № 1604) www.dy.nayka.com.ua | № 102018 p.|31.10.2018

УДК $350.78 ; 352$

\author{
B. В. Федорчак, \\ кандидат наук з державного управління, \\ докторант Навчально-науково-виробничого центру, \\ Національний університет циивільного захисту України, м. Харків

\section{ДОСЛІДЖЕННЯ ОСОБЛИВОСТЕЙ ДЕРЖАВНОГО УПРАВЛІННЯ МОНІТОРИНГОМ РИЗИКІВ ВИНИКНЕННЯ НАДЗВИЧАЙНИХ СИТУАЦЙ В УКРАЇНІ}

\author{
V. V. Fedorchak \\ PhD in public administration, doctoral candidate of the Educational, \\ Scientific and Production Centre, \\ National University of Civil Defence of Ukraine, Kharkiv
}

\title{
THE RESEARCH OF FEATURES OF PUBLIC ADMINISTRATION CONCERNING MONITORING OF RISKS OF EMERGENCIES IN UKRAINE
}

\begin{abstract}
У статті здійснено дослідження особливостей державного управління моніторингом ризиків виникнення надзвичайних ситуацій в Украӥні. Зокрема, проаналізовано структуру природних надзвичайних ситуацій за видами. Встановлено, щуо переважно були представлені медико-біологічними. Охарактеризовано розподіл техногенних надзвичайних ситуачій. Показано, щзо переважно техногенні надзвичайні ситуачіі представлені вибухами і пожежами. Очінено розподіл надзвичайних ситуацій відповідно до характеру їх походження та масштабу їх розповсюдження. Відмічено, щзо кількість техногенних $i$ природних надзвичайних ситуачій збільшилася удвічі, а кількість сочіальних надзвичайних ситуачій збільшилася у 6 разів. Також удвічі збільшилася кількість надзвичайних ситуачій на державному, регіональному, місцевому й об'єктовому рівнях. Визначено ризики виникнення надзвичайних ситуацій: порушення правил пожежної безпеки та дорожнього руху; знос переважної кількості основних фондів та аварійний стан більшості мереж, щуо знаходяться у відомстві комунального господарства; недотримання норм санітарно-гігієнічного характеру та недостатній контроль за впровадженням заходів протиепізоотичного та протиепідемічного характеру; аномальні атмосфері прояви тощчо.
\end{abstract}

Problem setting. Effective public administration in the sphere of emergencies demands a combination of the purposes, methods and means and is focused on stimulation of the state and administrative processes and also on providing of recurrence of functioning of system of such management and its planned character.

However the process of planning in emergencies' conditions depends on character of questions which are resolved and conditions in which these changes happen. This process is non-uniform and sometimes contradictory. Accordingly, it causes the relevance of the subject of research.

Recent research and publication analysis. The features of state regulation of emergencies' risks were the subject of research of many scientists in present conditions. 
However the features of the state monitoring of emergencies' risks at the state level remain insufficiently investigated.

Paper objective. The purpose of article is research of features of public administration concerning monitoring of risks of emergencies in Ukraine.

Paper main body. The research of features of public administration concerning monitoring of risks of emergencies in Ukraine is conducted in the article. In particular, the structure of natural emergencies by types is analyzed. The distribution of technogenic emergencies is characterized. The distribution of emergencies according to their nature and scale is estimated. Also the number of emergencies at the state, regional, local and object levels doubled. The following risks of emergencies are defined: violation of the rules of fire safety and traffic; wear of overwhelming quantity of fixed assets and critical condition of most municipal services networks; noncompliance with standards of sanitary and hygienic character and insufficient control of introduction of actions of anti-epizootic and anti-epidemic character; abnormal atmosphere phenomenon etc.

\section{Conclusions of the research.}

1. It is established that natural emergencies mainly are presented in the form of medicobiological ones.

2. It is shown that mainly technogenic emergencies are presented by explosions and fires.

3. It is noted that the number of technogenic and natural emergencies doubled, and the number of social emergencies increased by 6 times. Also the number of emergencies at the state, regional, local and object levels doubled.

Ключові слова: державне управління; моніторинг; ризики; надзвичайні ситуаиії.

Keywords: public administration; monitoring; risks; emergencies.

Постановка проблеми. Дієве державне управління у сфері НС вимагає поєднання цілей, методів і засобів впливу, яке покликано стимулювати державно-управлінські процеси, забезпечувати циклічність функціонування системи такого управління (з новими віхами), іiі плановість.

Однак процес планування в умовах НС залежно від характеру питань, що вирішуються, й умов в яких дані зміни відбуваються, $є$ неоднорідним, а іноді суперечливим. Відповідно, це обумовлює актуальність обраної теми дослідження.

Аналіз останніх досліджень і публікацій. В нинішніх умовах особливості здійснення державного регулювання ризиків надзвичайних ситуацій підлягали дослідженню з боку багатьох науковців, зокрема, таких, як: О. В. Бєлоусов [1], О. А. Дєгтяр [2], Д. Полковниченко [4] та ін.

Проте особливості державного моніторингу ризиків виникнення надзвичайних ситуацій на державному рівні залишаються недостатньо дослідженими.

Мета статті. Метою роботи є дослідження особливостей державного управління моніторингом ризиків виникнення надзвичайних ситуацій в Україні.

Для досягнення поставленої мети в роботі є доцільними постановка та вирішення таких завдань:

- проаналізувати структуру природних надзвичайних ситуацій за видами;

- охарактеризувати розподіл техногенних надзвичайних ситуацій;

- оцінити розподіл надзвичайних ситуацій відповідно до характеру їх походження та масштабу їх розповсюдження;

- визначити ризики виникнення надзвичайних ситуацій.

Виклад основного матеріалу.

Для проведення якісного дослідження особливостей державного управління моніторингом виникнення надзвичайних ситуацій в Україні, необхідно проаналізувати відповідні статистичні дані протягом останніх $2015-2017$ років.

При цьому фактично протягом 2015 року у структурі надзвичайних ситуацій техногенного характеру переважали ті, що виникли як наслідок вибухів і пожеж - $18 \%$ від загальної кількості зафіксованих надзвичайних ситуацій.

Що стосується природних надзвичайних ситуацій, то переважно вони були представлені медикобіологічними (40\% від загальної кількості зареєстрованих надзвичайних ситуацій).

Крім того, розподіл природних надзвичайних ситуацій у 2015 році за видами виглядає наступним чином (табл. 1 та рис. 1$)$. 
Таблиця 1.

Структура природних надзвичайних ситуацій за видами у 2015 році

\begin{tabular}{|c|c|}
\hline Вид надзвичайних ситуацій & Кількість \\
\hline Інфекційні людські захворювання & 27 \\
\hline $\begin{array}{c}\text { Захворювання сільськогосподарських тварин } \\
\text { інфекційного походження }\end{array}$ & 19 \\
\hline Отруєння людей & 13 \\
\hline Пожежі на рівні природних екологічних систем & 2 \\
\hline Надзвичайні ситуації метеорологічного походження & 2 \\
\hline Надзвичайні ситуації геологічного походження & 1 \\
\hline Надзвичайні ситуації гідрологічного походження & 77 \\
\hline Усього & \\
\hline
\end{tabular}

Серед ризиків настання та розвитку природних i техногенних надзвичайних ситуацій в Україні протягом 2015 року Державна служба України з надзвичайних ситуацій виділяє такі:

- порушення правил пожежної безпеки та дорожнього руху;

- наявність порушень правил перевезення, зберігання і застосування речовин небезпечного характеру;

- знос переважної кількості основних фондів та аварійний стан більшості мереж, що знаходяться у відомстві комунального господарства;

- недотримання норм санітарно-гігієнічного характеру та недостатній контроль за впровадженням заходів протиепізоотичного та протиепідемічного характеру;

- аномальні атмосфері прояви тощо.

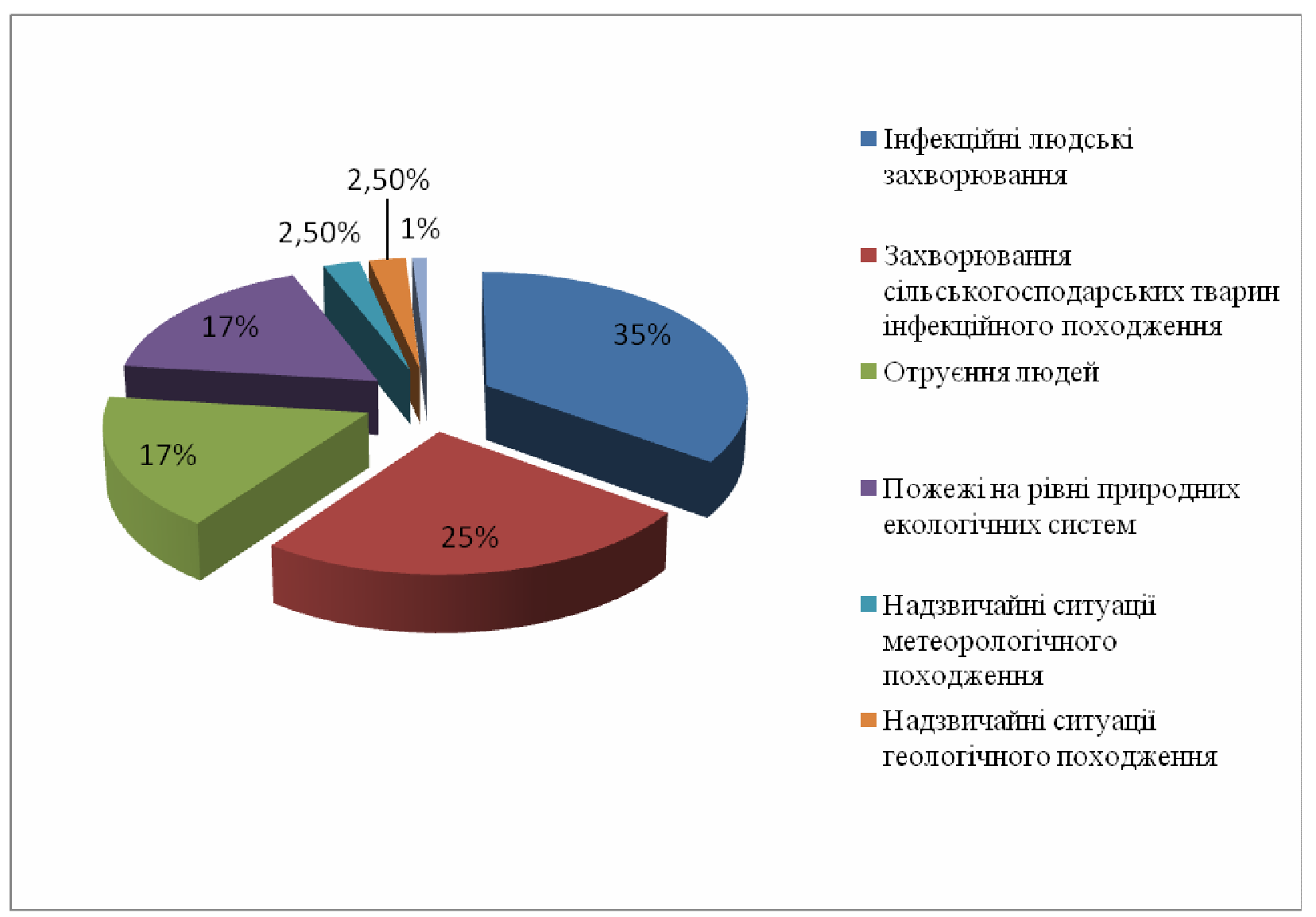

Рисунок 1. Розподіл надзвичайних ситуацій за видами у 2015 році

Що стосується 2016 року, то розподіл природних надзвичайних ситуацій протягом даного періоду виглядає наступним чином (табл. 2 та рис. 2). 
Таблиця 2.

Структура природних надзвичайних ситуацій за видами у 2016 році

\begin{tabular}{|c|c|}
\hline Вид надзвичайних ситуацій & Кількість \\
\hline Медико-біологічні & 78 \\
\hline Пожежі на рівні природних екологічних систем & 4 \\
\hline Надзвичайні ситуації метеорологічного походження & 6 \\
\hline Надзвичайні ситуації геологічного походження & 1 \\
\hline Надзвичайні ситуації гідрологічного походження & - \\
\hline Усього & 89 \\
\hline
\end{tabular}

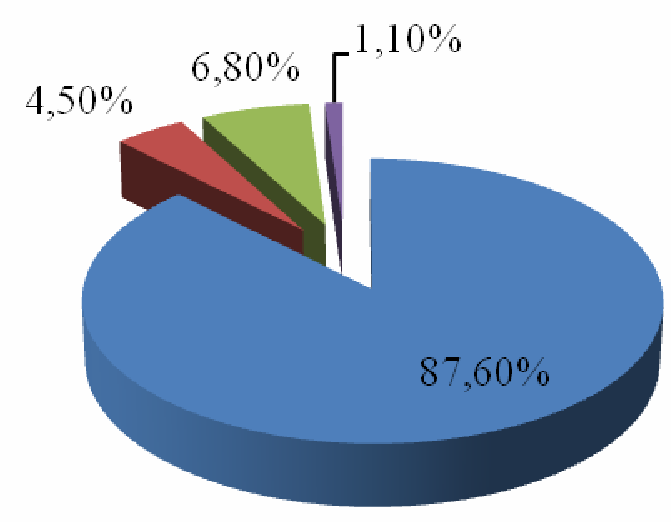

- Медико-біологічні

- Пожежі на рівні прнродних екологічнгх систем

Надзвнчайні ситу ації метеорологічного походження

- Надзвичайні ситу ації геологічного походження

- Надзвичайні ситу ації гідр ологічного походження

Рисунок 2. Розподіл природних надзвичайних ситуацій за видами у 2016 році

3 табл. 2 та рис. 2 можна побачити, що протягом 2016 року переважну кількість надзвичайних ситуацій природного походження склали також медико-біологічні $(87,6 \%$ від загальної кількості зареєстрованих природних надзвичайних ситуацій).

Розподіл техногенних надзвичайних ситуацій протягом 2016 року виглядає наступним чином (табл. 3 та рис. 3).

Таблиця 3.

Структура техногенних надзвичайних ситуацій за видами у 2016 році

\begin{tabular}{|c|c|}
\hline Вид надзвичайних ситуацій & Кількість \\
\hline Транспорті аварії та катастрофи & 11 \\
\hline Вибухи та пожежі & 36 \\
\hline $\begin{array}{c}\text { Аварії в будівлях та спорудах житлового } \\
\text { призначення }\end{array}$ & 9 \\
\hline Усього & 56 \\
\hline
\end{tabular}




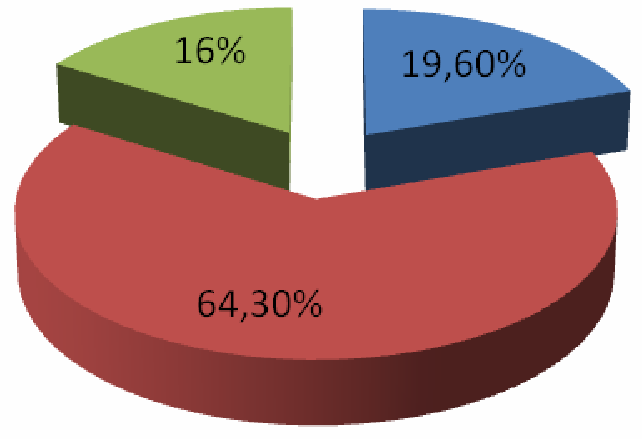

- Транспорті аварії та катастрофи

Вибухи та пожежі

Аварії в будівлях та спорудах житлового призначення

Рисунок 3. Розподіл природних надзвичайних ситуацій за видами у 2016 році

3 табл. 3 та рис. 3 можна побачити, що переважно техногенні надзвичайні ситуації у 2016 році були представлені вибухами і пожежами (64,3\% від загальної кількості зареєстрованих надзвичайних ситуацій техногенного походження).

Серед ключових ризиків виникнення природних і техногенних надзвичайних ситуацій упродовж 2016 року Державна служба України з надзвичайних ситуацій виділяє наступні:

- порушення правил пожежної безпеки та дорожнього руху;

- знос переважної кількості основних фондів та аварійний стан більшості мереж, що знаходяться у відомстві комунального господарства;

- недотримання норм санітарно-гігієнічного характеру та недостатній контроль за впровадженням заходів протиепізоотичного та протиепідемічного характеру;

- аномальні атмосфері прояви тощо.

Якщо звернутися до статистики 2017 року, то порівняльну характеристику кількості надзвичайних ситуацій техногенного та природного характеру протягом першого півріччя та 9 місяців зазначеного періоду наведено у табл. 4 та табл. 5 відповідно.

Відсотковий розподіл кількості надзвичайних ситуацій, зареєстрованих в Україні, відповідно до характеру їх походження та масштабу їх розповсюдження, протягом 9 місяців 2017 року відповідно, наведений на рис. 4 та рис. 5 відповідно.

Таблиця 4.

Розподіл надзвичайних ситуацій, заресстрованих в Україні протягом І півріччя 2017 року, відповідно до характеру їх походження

\begin{tabular}{|l|c|c|}
\hline \multicolumn{1}{|c|}{ Категорія надзвичайних ситуацій } & $\begin{array}{l}\text { Кількість, } \\
\text { І півріччя }\end{array}$ & Кількість, 9 місяців \\
\hline Техногенні & 21 & 41 \\
\hline Природні & 47 & 91 \\
\hline Соціальні & 1 & 6 \\
\hline Усього & 69 & 138 \\
\hline
\end{tabular}


Таблиця 5.

Розподіл надзвичайних ситуацій, заресстрованих в Україні протягом

І півріччя 2017 року, відповідно до масштабу їх розповсюдження

\begin{tabular}{|l|c|c|}
\hline \multicolumn{1}{|c|}{ Рівень надзвичайної ситуації } & $\begin{array}{l}\text { Кількість, } \\
\text { І півріччя }\end{array}$ & Кількість, 9 місяців \\
\hline Державний & 1 & 2 \\
\hline Регіональний & 3 & 7 \\
\hline Місцевий & 32 & 73 \\
\hline Об'єктовий & 33 & 138 \\
\hline Усього & 69 & \\
\hline
\end{tabular}

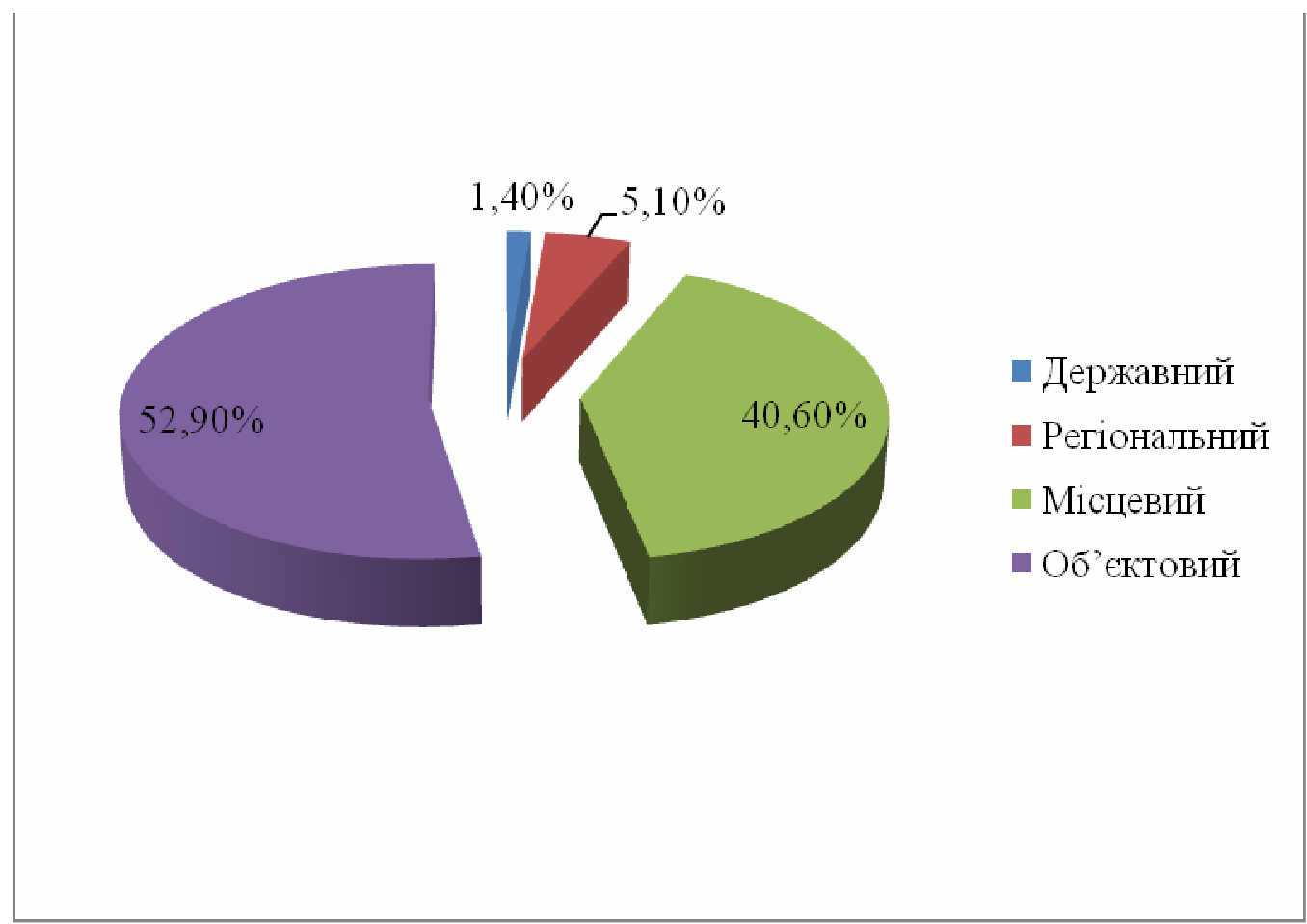

Рисунок 4. Відсотковий розподіл кількості надзвичайних ситуацій, заресстрованих в Украӥні, відповідно до масштабу їх розповсюдження, протягом 9 місяців 2017 року

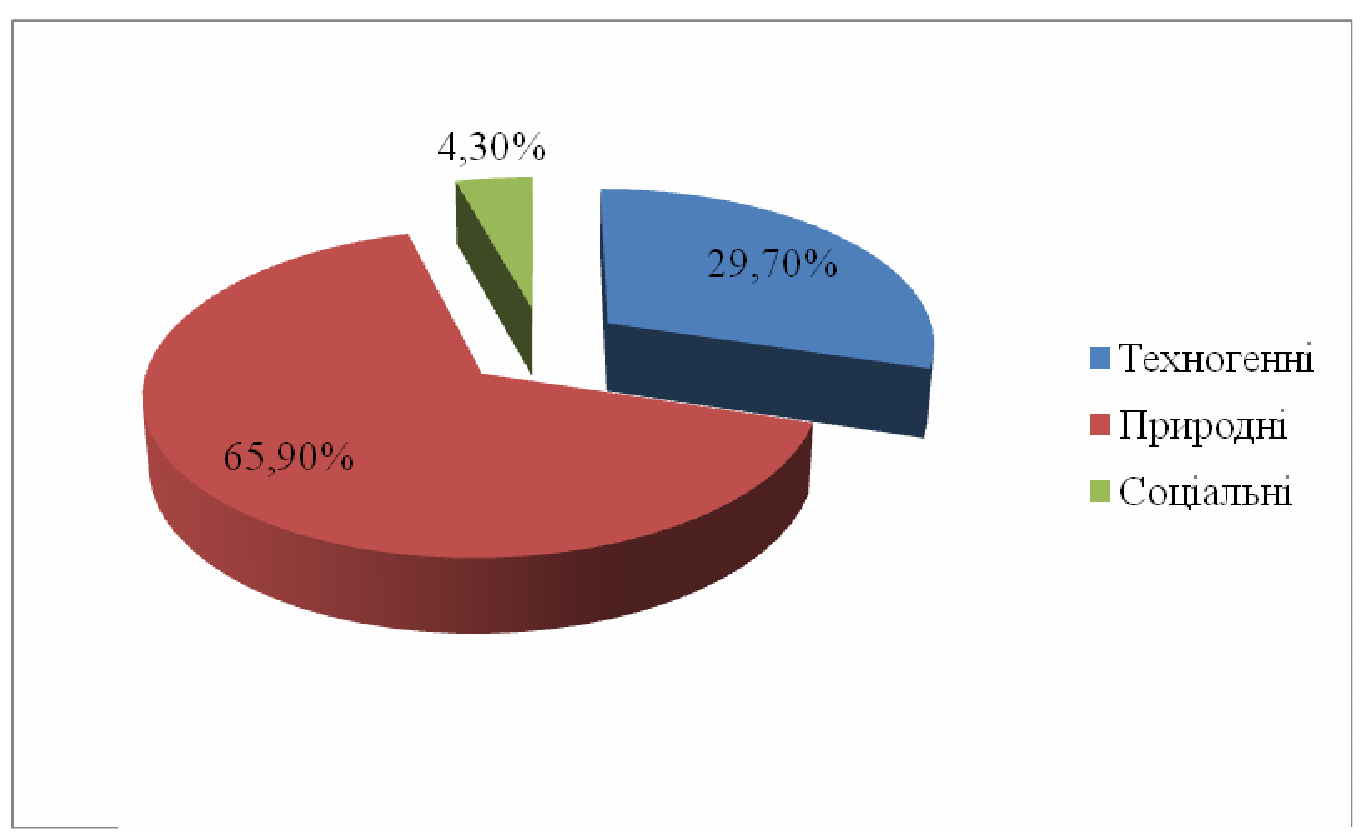

Рисунок 5. Відсотковий розподіл кількості надзвичайних ситуацій, заресстрованих в Україні, відповідно до характеру їх походження, протягом 9 місяців 2017 року 
Як можна побачити 3 табл. 4 та рис. 4, кількість техногенних надзвичайних ситуацій збільшилася протягом 9 місяців 2017 року порівняно з першим півріччям 2017 року удвічі. Майже удвічі збільшилася кількість природних надзвичайних ситуацій. А кількість соціальних надзвичайних ситуацій збільшилася у 6 разів.

Як можна побачити 3 табл. 5 та рис. 5, кількість надзвичайних ситуацій на державному рівні збільшилася удвічі. Відповідно, більше, ніж у 2 рази підвищилася кількість надзвичайних ситуацій на регіональному рівні. Практично в 2 рази підвищилася кількість надзвичайних ситуацій на місцевому рівні та більше ніж в 2 рази - на об'єктовому рівні.

Висновки 3 даного дослідження та перспективи подальших розвідок у даному напрямку. Таким чином, в результаті проведення даного дослідження було отримано такі результати.

1. Проаналізовано структуру природних надзвичайних ситуацій за видами. Встановлено, що переважно вони були представлені медико-біологічними (40\% від загальної кількості зареєстрованих природних надзвичайних ситуацій - у 2015 році та 87,6\% - у 2016 році).

2. Охарактеризовано розподіл техногенних надзвичайних ситуацій. Показано, що переважно техногенні надзвичайні ситуації у 2016 році були представлені вибухами і пожежами (64,3\% від загальної кількості зареєстрованих надзвичайних ситуацій техногенного походження).

3. Оцінено розподіл надзвичайних ситуацій відповідно до характеру їх походження та масштабу їх розповсюдження. Відмічено, що кількість техногенних надзвичайних ситуацій збільшилася протягом 9 місяців 2017 року порівняно з першим півріччям 2017 року удвічі. Майже удвічі збільшилася кількість природних надзвичайних ситуацій. А кількість соціальних надзвичайних ситуацій збільшилася у 6 разів.

Крім того, кількість надзвичайних ситуацій на державному рівні збільшилася удвічі. Відповідно, більше, ніж у 2 рази підвищилася кількість надзвичайних ситуацій на регіональному рівні. Практично в 2 рази підвищилася кількість надзвичайних ситуацій на місцевому рівні та більше ніж в 2 рази - на об'єктовому рівні.

4. Визначено ризики виникнення надзвичайних ситуацій. Зроблено наголос на наступних ключових позиціях: порушення правил пожежної безпеки та дорожнього руху; знос переважної кількості основних фондів та аварійний стан більшості мереж, що знаходяться у відомстві комунального господарства; недотримання норм санітарно-гігієнічного характеру та недостатній контроль за впровадженням заходів протиепізоотичного та протиепідемічного характеру; аномальні атмосфері прояви тощо.

\section{Література.}

1. Бєлоусов А. В. Методологічні аспекти удосконалення системи державного управління ризиками надзвичайних ситуацій / А. В. Бєлоусов // Інвестиції: практика та досвід. - 2014. - № 11. - С. 131-134.

2. Дєгтяр О. А. Напрями удосконалення засобів управління соціальним ризиком / О. А. Дєгтр, О. М. Непомнящий // Вісник Національного університету цивільного захисту України. Серія. Державне управління. - 2017. - Вип. 1 (6). - С. 1-9.

3. Кравців С. Я. Ризик-орієнтований підхід у державному регулюванні у сфері техногенної та пожежної безпеки / С. Я. Кравців, О.М.Соболь, А. Г. Коссе // Вісник Національного університету цивільного захисту України. Серія. Державне управління. - 2017. - Вип. 1 (6). - С. 336-341.

4. Полковниченко Д. Державна політика у сфері попередження надзвичайних ситуацій на основі концепції ризиків [Електронний ресурс] / Д. Полковниченко // Теорія та практика державного управління. 2013. -№ 4. - Режим доступу: http://www.kbuapa.kharkov.ua/e-book/conf/2013-4/doc/3.pdf

\section{References.}

1. Belousov A.V. (2014) "Metodolohichni aspekty udoskonalennya systemy derzhavnoho upravlinnya ryzykamy nadzvychaynykh sytuatsiy" [Methodological aspects of improvement of system of public administration by risks of emergency situations], Kyiv, Ukraine.

2. Dyehtyar O. A. (2017) "Napryamy udoskonalennya zasobiv upravlinnya sotsial'nym ryzykom" [Directions of improvement of control facilities of social risk], Kharkiv, Ukraine.

3. Kravtsiv S. Ya. (2017) “ Ryzyk-oriyentovanyy pidkhid u derzhavnomu rehulyuvanni u sferi tekhnohennoyi ta pozhezhnoyi bezpeky" [The risk-focused approach in public administration in the sphere of technogenic and fire safety], Kharkiv, Ukraine.

4. Polkovnychenko D. (2013) “ Derzhavna polityka u sferi poperedzhennya nadzvychaynykh sytuatsiy na osnovi kontseptsiyi ryzykiv" [State policy in the sphere of prevention of emergencies on the basis of the concept of risks], Kyiv, Ukraine. 